\title{
Estiolamento e regeneração na multiplicação in vitro do abacaxizeiro híbrido PE x SC-52(1)
}

\author{
Sarah Brandão Santa Cruz Barboza(2) e Linda Styer Caldas ${ }^{(3)}$
}

\begin{abstract}
Resumo - Segmentos nodais estiolados são utilizados para a micropropagação e conservação da identidade genética em várias culturas. O objetivo deste trabalho foi avaliar a multiplicação in vitro de segmentos estiolados para produção de mudas do abacaxi híbrido PE x SC-52. Talos de plântulas produzidos in vitro receberam inóculo em tubos de ensaio contendo o meio de cultura MS e mantidos no escuro por 60 dias, para estiolamento. Foram utilizados três tratamentos, sem reguladores de crescimento,ANA a $1,86 \mathrm{mg} / \mathrm{L}$ e AIAa $1,75 \mathrm{mg} / \mathrm{L}$ em cinco repetições com dez explantes por repetição. Não houve diferença no número de brotos estiolados por explante entre os tratamentos avaliados. No entanto, aos 35 dias de cultivo, os tratamentos com ANA e AIA apresentavam maior número de nós por broto, sendo o ANA superior aos demais após 60 dias. Brotos estiolados in vitro por 60 dias foram colocados horizontalmente em placas de Petri contendo o meio MS e incubados na presença de luz. Foram usados quatro tratamentos para a regeneração das plântulas, sem reguladores de crescimento; BAP a $2 \mathrm{mg} / \mathrm{L}$; ANA a $1,86 \mathrm{mg} / \mathrm{L}+\mathrm{BAP}$ a $2 \mathrm{mg} / \mathrm{L}$ e CIN a $5 \mathrm{mg} / \mathrm{L}$, em quatro repetições, com sete brotos estiolados, por repetição. O BAP promoveu maior número de plântulas regeneradas por broto e por nó, com uma média de 10,4 plântulas por broto estiolado, aos 30 dias
\end{abstract}

Termos para indexação: Ananas comosus, cultura in vitro, micropropagação, propagação de plantas.

\section{Etiolation and regeneration in the in vitro multiplication of hybrid PE x SC-52 pineapple}

\begin{abstract}
Etiolated nodal segments are used for micropropagation and conservation of the genetic identity of several crops. The present study evaluated this method for the multiplication of the pineapple hybrid PE x SC-52. Plantlet stems produced in vitro were inoculated in test tubes containing MS nutrient medium and maintained in darkness for 60 days for etiolation. Three treatments were used with growth-regulator free MS medium; NAA at $1.86 \mathrm{mg} / \mathrm{L}$, and IAA at $1.75 \mathrm{mg} / \mathrm{L}$, with five repetitions and ten explants per repetition. There was no difference among the treatments in the number of etiolated shoots, per explant. However, NAA and IAA, after 35 days, produced a greater number of nodes per shoot, and NAA was the most efficient after 60 days. Etiolated shoots were placed horizontally in Petri dishes containing MS medium and incubated in the presence of light. Four treatments were used for the regeneration of plantlet growth-regulator free MS medium; BAP at $2 \mathrm{mg} / \mathrm{L}$; NAA at $1.86 \mathrm{mg} / \mathrm{L}+\mathrm{BAP}$ at $2 \mathrm{mg} / \mathrm{L}$, and $\mathrm{KIN}$ at $5 \mathrm{mg} / \mathrm{L}$ with four repetitions and seven etiolated shoots per repetition. BAP promoted the largest number of regenerated plantlets per shoot and per node, with an average of 10.4 plantlets per shoot after 30 days
\end{abstract}

Index terms: Ananas comosus, in vitro culture, micropropagation, plant propagation.

(1) Aceito para publicação em 27 de junho de 2000. Extraído da dissertação de mestrado apresentada pelo primeiro autor à Universidade de Brasília (UnB), DF.

${ }^{(2)}$ Empresa de Desenvolvimento Agropecuário (EMDAGRO)/ Embrapa-Centro de Pesquisa Agropecuária dos Tabuleiros Costeiros (CPATC), Caixa Postal 44, CEP 49001-970 Aracaju, SE. E-mail: sarahb@zaz.com.br

(3)UnB, Caixa Postal 04457, CEP 70919-970 Brasília, DF. E-mail: 1scaldas@unb.br

\section{Introdução}

Na cultura do abacaxi, a qualidade da muda tem influência tão forte no estado sanitário, desenvolvimento, produção e rendimento das plantações que a obtenção e utilização de material de plantio com vigor e sanidade superiores podem ser considerados fatores decisivos para se alcançar sucesso econômico no cultivo desta fruteira (Reinhardt, 1998). 
A utilização de mudas de abacaxi produzidas em laboratório no Brasil ainda é restrita, pelo reduzido número de laboratórios e pelo preço da muda relativamente elevado. Essa técnica pode ser utilizada para a multiplicação rápida de genótipos selecionados em programas de melhoramento genético, disponibilizando maior quantidade de mudas em curto período de tempo e, posteriormente, para a produção de mudas de novas cultivares (Pasqual et al., 1998).

A proliferação de gemas axilares é, geralmente, preferida na micropropagação. É comum ocorrerem simultaneamente a proliferação de gemas axilares e a formação de gemas adventícias na base do explante. Gemas adventícias são desejáveis, desde que a formação do calo seja mínima ou nula. Nesta condição, os dois fenômenos dificilmente podem ser separados, pois ambos se devem à ação da citocinina do meio de cultura sobre todo o tecido (Grattapaglia \& Machado, 1998).

Níveis elevados de variabilidade morfológica em plantas da cultivar Smooth Cayenne regeneradas in vitro a partir de calos, em comparação às culturas de gemas axilares de coroas, foram relatados por Wasaka (1979), o que comprometia o uso dessa técnica para fins comerciais. Outras observações sobre heterogeneidade entre plantas regeneradas foram relatadas por Rao et al. (1981) e Dewald et al. (1988). Ramirez (1984) observou considerável heterogeneidade em folhas e raízes de plântulas derivadas de gemas da coroa da cultivar Red Spanish em meio de cultura com ANA e cinetina, enquanto Ventura et al. (1993) não observaram variações fenotípicas.

Embora algumas variantes possam proporcionar características vantajosas, tais como o formato da folha e do fruto, a coloração, a ausência de espinhos na folha (Kiss et al., 1992), a manutenção da identidade genotípica e fenotípica, são indispensáveis para a propagação em massa de genótipos selecionados e novas cultivares (Kiss et al., 1995).

A utilização de segmentos nodais para a micropropagação e conservação da estabilidade genética foi demonstrada com batata (Heszky \& Nagy, 1987), alfafa (Dudits et al., 1991) e fumo (Maliga et al.,1975). Kiss et al. (1995) desenvolveram um método para produção de mudas de abacaxi in vitro, usando segmentos nodais estiolados. Segundo estes autores, 80.000 plantas podem ser regeneradas no período de um ano através de uma planta primária, com a vantagem de evitar lesões na zona de regeneração, impedindo a formação de calo. Com isso, é possível que o método proporcione baixos níveis de variabilidade fenotípica.

O objetivo deste trabalho foi avaliar a multiplicação in vitro do abacaxizeiro híbrido PE x SC-52, utilizando o estiolamento de segmentos nodais e posterior regeneração de brotos.

\section{Material e Métodos}

O trabalho foi realizado no Laboratório de Fisiologia Vegetal da Universidade de Brasília (UnB), utilizando-se o abacaxizeiro híbrido PE x SC-52, desenvolvido pelo programa de melhoramento genético da Embrapa-Centro Nacional de Pesquisa de Mandioca e Fruticultura, localizada em Cruz das Almas, BA. Este híbrido é um $\mathrm{F}_{1}$ do cruzamento Perolera $x$ Smooth Cayenne, selecionado no ciclo sexual e, posteriormente, submetido a duas avaliações clonais. Possui folhas sem espinhos, e se comportou como resistente à fusariose, mediante inoculação artificial.

\section{Estiolamento}

Foram utilizadas plântulas com 5 a $7 \mathrm{~cm}$ de altura, produzidas in vitro a partir de gemas axilares de mudas tipo filhote. Estas foram totalmente desfolhadas, deixando-se apenas o talo. O meio de cultura básico usado foi o MS (Murashige \& Skoog, 1962), suplementado com mioinositol a $100 \mathrm{mg} / \mathrm{L}$ e sacarose a $30 \mathrm{~g} / \mathrm{L}$, e solidificado com ágar a $7 \mathrm{~g} / \mathrm{L}$. O pH foi ajustado para 5,8 antes da autoclavagem, que foi realizada a $120^{\circ} \mathrm{C}$, por 15 minutos.

$\mathrm{O}$ delineamento experimental foi inteiramente casualizado, constituído de três tratamentos e cinco repetições (dez explantes/repetição), com os seguintes tratamentos: 1) sem regulador de crescimento; 2) com ANA a $1,86 \mathrm{mg} / \mathrm{L} ; 3$ ) com AIA a $1,75 \mathrm{mg} / \mathrm{L}$.

O preparo dos explantes e a inoculação no meio de cultura foram feitos em condições assépticas, colocando-se um explante (talo) por tubo de ensaio de $150 \mathrm{~mm} \mathrm{x}$ $25 \mathrm{~mm}$ contendo $15 \mathrm{~mL}$ de meio de cultura. Os tubos foram envoltos em papel-alumínio e mantidos por 60 dias em sala de incubação, com temperatura de $25 \pm 3^{\circ} \mathrm{C}$.

As avaliações ocorreram aos 35 e 60 dias de incubação, observando-se o número de brotos estiolados por explante, número de nós por broto estiolado e comprimento dos brotos 


\section{Regeneração}

Utilizaram-se brotos estiolados in vitro por 60 dias, que após eliminação das raízes foram colocados horizontalmente em placas de Petri de $9 \mathrm{~cm}$ de diâmetro e $2 \mathrm{~cm}$ de altura, contendo $40 \mathrm{~mL}$ de meio de cultura por placa O meio de cultura básico e os procedimentos de preparo foram os mesmos utilizados para o estiolamento.

O delineamento experimental foi o inteiramente casualizado, constituído de quatro tratamentos e quatro repetições (sete brotos estiolados/repetição), sendo os seguintes tratamentos para a regeneração: 1) sem reguladores de crescimento; 2) com CIN a $5 \mathrm{mg} / \mathrm{L}$; 3 ) com BAP a $2,0 \mathrm{mg} / \mathrm{L}+$ ANA a $1,86 \mathrm{mg} / \mathrm{L} ; 4) \mathrm{com}$ BAP a $2 \mathrm{mg} / \mathrm{L}$ As culturas foram mantidas em sala de incubação com intensidade luminosa de $50 \mu$ moles $\mathrm{m}^{-2} \mathrm{~s}^{-1}$, temperatura de $25 \pm 3^{\circ} \mathrm{C}$ e fotoperíodo de 16 horas.

Aos 30 dias, procedeu-se à avaliação do número de plântulas regeneradas por broto estiolado e por nó.

\section{Análise estatística}

Os dados foram submetidos a análise de variância e as médias foram comparadas pelo teste de Duncan a 5\% de probabilidade.

\section{Resultados e Discussão}

O número e o comprimento médio dos brotos estiolados produzidos por explante inicial foram estatisticamente iguais em todos os tratamentos, aos 35 dias de incubação no escuro (Tabela 1). No tratamento com ANA a $1,86 \mathrm{mg} / \mathrm{L}$ obteve-se 1,5 broto estiolado por explante com $5,5 \mathrm{~cm}$ de altura, enquanto os tratamentos com AIA a $1,75 \mathrm{mg} / \mathrm{L}$ e sem reguladores de crescimento formaram 1,4 e 1,5 brotos, respectivamente, com $4,8 \mathrm{~cm}$ de altura. Aos 35 dias de cultivo no escuro, os explantes estiolados na presença de ANA e AIA foram estatisticamente superiores, em número de nós por broto estiolado $(6,7$ e 6,2 nós, respectivamente), em relação ao tratamento sem reguladores de crescimento ( 4,8 nós) (Tabela 2). Tais resultados confirmam os obtidos por Kiss et al. (1995) que conseguiram uma média de 7 nós por broto, após 30-35 dias no escuro, utilizando explantes da cultivar Smooth Cayenne em meio contendo ANA a 1,86 mg/L. Os autores citados relatam que as brotações estioladas pararam o crescimento após cinco e seis semanas de incubação. Neste trabalho, transcorridos mais 25 dias, os brotos estiolados em meio de cultura contendo ANA tiveram um acréscimo de 4,6 nós por broto, enquanto, no mesmo período, os tratamentos sem reguladores de crescimento e com AIA apresentaram acréscimos de 2,8 e 2,7 nós, respectivamente, em cada broto estiolado (Tabela 2).

O crescimento no segundo mês foi mais lento, principalmente nos tratamentos com AIA e sem reguladores de crescimento, nos quais foram obtidos, respectivamente, apenas $43 \%$ e $58 \%$ do número de nós formados no primeiro mês. Ao final de 60 dias no escuro, formaram-se, em média, 11,3 nós em cada broto estiolado, em presença de ANA (Figura 1), sendo estatisticamente superior aos valores de 8,9 e 7,6 nós obtidos nos tratamentos com AIA (Figura 2A) e sem reguladores (Figura 2B). Roca et al. (1978) e Marinus (1984), trabalhando com batata em meio de cultura contendo auxinas, conseguiram uma média

Tabela 1. Número e comprimento de brotos estiolados por explante do abacaxi híbrido PE x SC-52, em diferentes tratamentos, após 35 dias no escuro ${ }^{(1)}$.

\begin{tabular}{lcc}
\hline Tratamento & $\begin{array}{c}\text { Brotos } \\
\text { estiolados/explante }\end{array}$ & $\begin{array}{c}\text { Comprimento } \\
\text { de brotos }(\mathrm{cm})\end{array}$ \\
\hline Sem reguladores & $1,6 \mathrm{a}$ & $4,8 \mathrm{a}$ \\
ANA a $1,86 \mathrm{mg} / \mathrm{L}$ & $1,5 \mathrm{a}$ & $5,5 \mathrm{a}$ \\
AIA a $1,75 \mathrm{mg} / \mathrm{L}$ & $1,4 \mathrm{a}$ & $4,8 \mathrm{a}$ \\
\hline
\end{tabular}

(1)Médias seguidas da mesma letra, na coluna, não diferem entre si pelo teste de Duncan $(\mathrm{p} \leq 0,05)$

Tabela 2. Número de nós por broto estiolado do abacaxi híbrido PE x SC-52 em diferentes tratamentos, após 35 e 60 dias no escuro. O número total de nós/broto estiolado é calculado com base no número de brotos/explante (Tabela 1) ${ }^{(1)}$.

\begin{tabular}{|c|c|c|c|c|}
\hline \multirow[t]{2}{*}{ Tratamento } & \multicolumn{3}{|c|}{$\mathrm{N}^{\mathrm{o}}$ de nós/broto estiolado } & \multirow{2}{*}{$\begin{array}{l}\mathrm{N}^{\mathrm{o}} \text { total de } \\
\text { nós/explante }\end{array}$} \\
\hline & Aos 35 dias & $\begin{array}{c}\text { Acréscimo de nós entre } \\
35 \text { e } 60 \text { dias }\end{array}$ & Aos 60 dias & \\
\hline Sem reguladores & $4,8 b$ & $2,8 \mathrm{~b}$ & $7,6 \mathrm{~b}$ & $12,2 b$ \\
\hline ANA a $1,86 \mathrm{mg} / \mathrm{L}$ & $6,7 \mathrm{a}$ & $4,6 a$ & $11,3 \mathrm{a}$ & $17,0 \mathrm{a}$ \\
\hline AIA a $1,75 \mathrm{mg} / \mathrm{L}$ & $6,2 \mathrm{a}$ & $2,7 \mathrm{~b}$ & $8,9 \mathrm{~b}$ & $12,5 \mathrm{~b}$ \\
\hline
\end{tabular}

${ }^{(1)}$ Médias seguidas de mesma letra, na coluna, não diferem entre si pelo teste de Duncan ( $\left.\mathrm{p} \leq 0,05\right)$. 


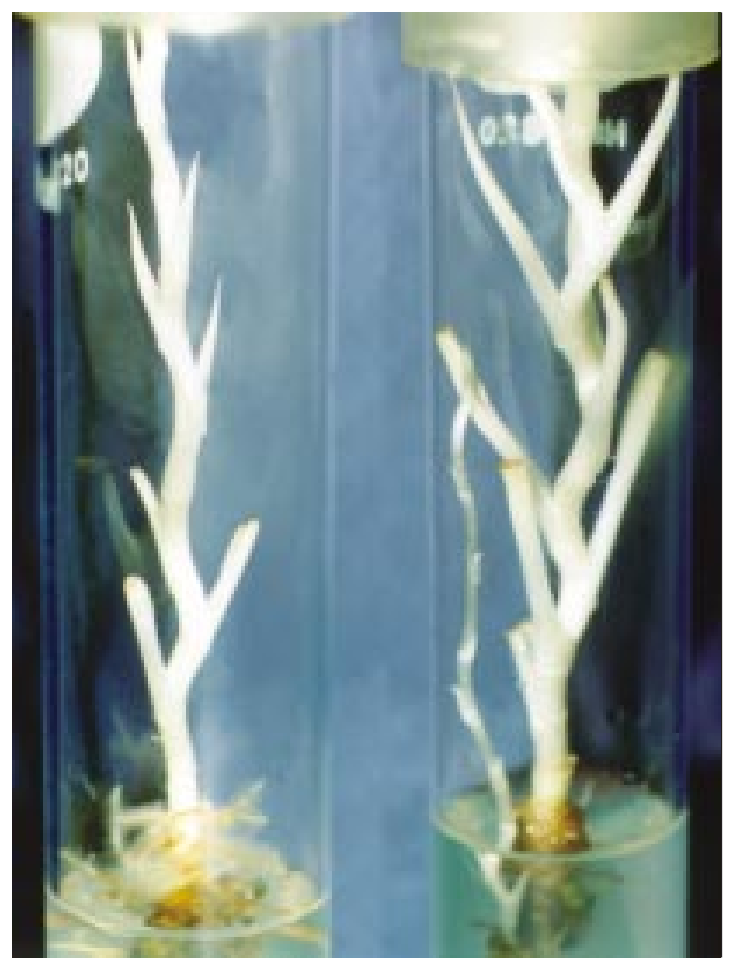

Figura 1. Brotos de abacaxi híbrido PE x SC-52 estiolados em meio MS com ANA a $1,86 \mathrm{mg} / \mathrm{L}$

de 5 nós por broto estiolado. O AIA é considerado uma auxina instável e, além da foto-oxidação, reações oxidativas catalisadas por enzimas também estão envolvidas no controle dos níveis desta auxina em folhas, caules e raízes (Válio, 1986). As diferenças em metabolismo e estabilidade das auxinas podem contribuir para diferentes respostas in vitro. A instabilidade do AIA, aliada à sua inativação ou destruição metabólica nas células, pode estar relacionada com o crescimento mais lento dos explantes, no segundo mês de cultivo, quando se utilizou esta auxina.

No escuro, os entrenós do talo da plântula do abacaxizeiro se alongaram, separando os nós que, normalmente, em presença de luz, permanecem próximos uns aos outros. Há muito tempo este comportamento tem sido observado em plantas crescendo no escuro. Para fins de micropropagação, a separação dos nós facilita o desenvolvimento de gemas axilares e a manipulação de plântulas regeneradas.



Figura 2. Brotos de abacaxi híbrido PE x SC-52 estiolados em meio MS com AIA a $1,75 \mathrm{mg} / \mathrm{L}$ (A) e sem reguladores de crescimento (B).

$\mathrm{O}$ número de plântulas regeneradas por broto estiolado, aos 30 dias de cultivo em meio MS, variou com o tipo, com a combinação de reguladores de crescimento, e com o número de nós em cada broto estiolado (Tabela 3). O tratamento com BAP a $2 \mathrm{mg} / \mathrm{L}$ foi mais eficiente para regenerar plântulas, independentemente do número de nós nos brotos, obtendo-se, em média, 10,4 plântulas por broto estiolado. Quando se associou ANA a $1,86 \mathrm{mg} / \mathrm{L}$ ao BAP, o número médio de plântulas regeneradas por broto caiu para 8,2. Os valores médios de plântulas regeneradas em meio com cinetina foram estatisticamente iguais aos obtidos com ANA + BAP. Em meio sem reguladores, a regeneração de plântulas foi inferior à dos demais tratamentos ( 2,9 plântulas por broto), observando-se, ainda, que o número de plântulas regeneradas em cada broto estiolado foi maior em explantes maiores.

A média de plântulas regeneradas em cada nó foi superior para o BAP, exceto nos brotos com 1 a 4 
Tabela 3. Efeito de diferentes tratamentos no número de plântulas regeneradas por broto estiolado do abacaxi híbrido PE x SC-52, no período de 30 dias $^{(1)}$.

\begin{tabular}{|c|c|c|c|c|c|}
\hline Tratamento & $\begin{array}{l}\text { Brotos c/ } \\
1 \text { a } 4 \text { nós }\end{array}$ & $\begin{array}{l}\text { Brotos c/ } \\
5 \text { a } 8 \text { nós }\end{array}$ & $\begin{array}{l}\text { Brotos c/ } \\
9 \text { a } 12 \text { nós }\end{array}$ & $\begin{array}{l}\text { Brotos c/ } \\
13 \text { a } 16 \text { nós }\end{array}$ & Média \\
\hline & \multicolumn{5}{|c|}{ Plântulas regeneradas /broto estiolado } \\
\hline Sem reguladores & $1,2 \mathrm{Bb}$ & $3,6 \mathrm{Ca}$ & $3,1 \mathrm{Ca}$ & $3,8 \mathrm{Ca}$ & $2,9 \mathrm{C}$ \\
\hline $\mathrm{CIN}$ a $5 \mathrm{mg} / \mathrm{L}$ & $5,5 \mathrm{Ab}$ & $5,7 \mathrm{BCb}$ & $8,6 \mathrm{Ba}$ & $8,4 \mathrm{BCa}$ & $7,1 \mathrm{~B}$ \\
\hline $\mathrm{BAP}$ a $2 \mathrm{mg} / \mathrm{L}$ + ANA a $1,86 \mathrm{mg} / \mathrm{L}$ & $6,7 \mathrm{Ab}$ & 7,7Bab & $8,9 \mathrm{Bab}$ & $9,7 \mathrm{Ba}$ & $8,2 \mathrm{~B}$ \\
\hline \multirow[t]{2}{*}{$\mathrm{BAP}$ a $2 \mathrm{mg} / \mathrm{L}$} & $6,0 \mathrm{Ab}$ & $10,8 \mathrm{Aa}$ & $13,6 \mathrm{Aa}$ & $16,1 \mathrm{Aa}$ & $10,4 \mathrm{~A}$ \\
\hline & \multicolumn{5}{|c|}{ Plântulas regeneradas /nó } \\
\hline Sem reguladores & $0,9 \mathrm{Ba}$ & $0,6 \mathrm{Ca}$ & $0,3 \mathrm{Cb}$ & $0,3 \mathrm{Cb}$ & $0,5 \mathrm{~B}$ \\
\hline $\mathrm{CIN}$ a $5 \mathrm{mg} / \mathrm{L}$ & $1,4 \mathrm{Aa}$ & $1,0 \mathrm{Bab}$ & $0,9 \mathrm{Bb}$ & $0,6 \mathrm{Bb}$ & $1,0 \mathrm{~A}$ \\
\hline $\mathrm{BAP}$ a $2 \mathrm{mg} / \mathrm{L}$ + ANA a $1,86 \mathrm{mg} / \mathrm{L}$ & $1,3 \mathrm{Aa}$ & $1,1 \mathrm{Ba}$ & $0,8 \mathrm{Bab}$ & $0,7 \mathrm{Bb}$ & $1,0 \mathrm{~A}$ \\
\hline BAP a $2 \mathrm{mg} / \mathrm{L}$ & $1,3 \mathrm{Aa}$ & $1,6 \mathrm{Aa}$ & $1,3 \mathrm{Aa}$ & $1,1 \mathrm{Aa}$ & $1,3 \mathrm{~A}$ \\
\hline
\end{tabular}

${ }^{(1)}$ Médias seguidas de mesma letra, maiúscula na coluna e minúscula na linha, não diferem entre si pelo teste de Duncan $(\mathrm{p} \leq 0,05)$.

nós (Tabela 3). O número de plântulas regeneradas por nó em brotos com 5 a 8 nós; 9 a 12 nós e 13 a 16 nós foi igual, a $5 \%$ de probabilidade, nos tratamentos com cinetina e ANA + BAP. No tratamento sem reguladores de crescimento ocorreu menor regeneração de plântulas por nó.

Em todos os tratamentos houve uma tendência de redução do número de plântulas regeneradas por nó à medida que o número de nós em cada broto aumentava (Tabela 3). Nos brotos menores, com 1 a 4 nós, o número de plântulas regeneradas por nó variou de 0,9 a 1,4 enquanto nos brotos maiores, com 13 a 16 nós, os valores ficaram entre 0,3 e 1,1 plântula. Em meio para regeneração contendo BAP + ANA ocorreu formação de massas de gemas nos nós, embora estas não tenham se desenvolvido em brotos alongados que pudessem ser contados, no período avaliado. Segundo Kiss et al. (1995), a taxa de regeneração de mais de um broto por nó indica que foram formadas gemas adventícias.

Nos tratamentos com BAP e CIN (Figuras 3 e 4) ocorreu a formação de plântulas bem definidas, embora um pouco menores que as plântulas formadas em meio sem hormônio. Brotações estioladas bem finas, quando colocadas em meio para regeneração com CIN, formaram pequenas plântulas na maioria dos nós (Figura 5B), e no tratamento com BAP ocorreu proliferação de gemas com formação de mais de uma plântula (Figura 5A). Na presença de ANA + $\mathrm{BAP}$, as plântulas eram pequenas, e formaram-se gemas em suas bases (Figura 6). Aumentando o pe-

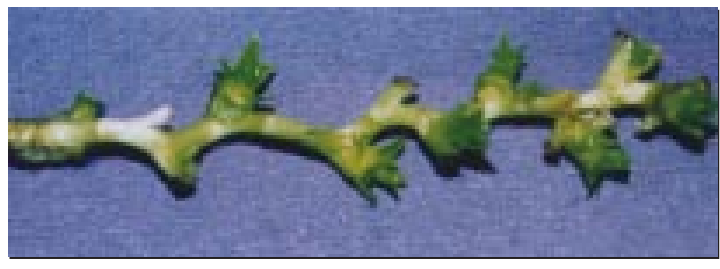

Figura 3. Plântulas de abacaxi híbrido PE x SC-52 regeneradas em meio MS com BAP a $2 \mathrm{mg} / \mathrm{L}$.

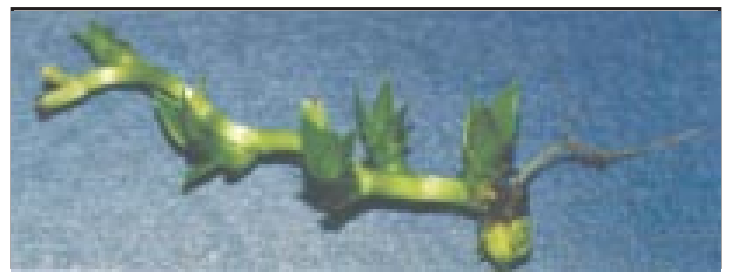

Figura 4. Plântulas de abacaxi híbrido PE x SC-52 regeneradas em meio MS com CIN a $5 \mathrm{mg} / \mathrm{L}$.

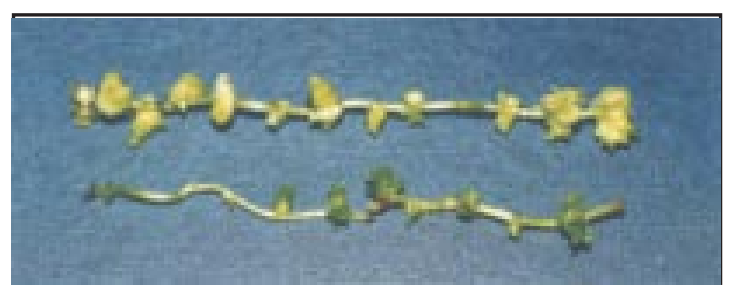

Figura 5. Plântulas de abacaxi híbrido PE x SC-52 regeneradas em meio MS com BAP a $2 \mathrm{mg} / \mathrm{L}$ (A) e com CIN a $5 \mathrm{mg} / \mathrm{L}(\mathrm{B})$. 
ríodo de cultivo por mais 15 ou 20 dias, este tratamento possivelmente poderia superar o tratamento com BAP, em razão da regeneração de plântulas das gemas adventícias. As plântulas regeneradas em meio sem reguladores de crescimento eram bem formadas, maiores e apresentavam raízes (Figura 7).

A proliferação de gemas axilares, por reproduzir in vitro um fenômeno natural, é um sistema mais facilmente controlado e apresenta fidelidade genética elevada (Grattapaglia \& Machado, 1998). No entanto, pelo fato de as bromélias serem particularmente propensas a variações genotípicas e fenotípicas em cultivo de tecidos, não se pode garantir que na regeneração de plantas a partir de segmentos nodais não se formem variantes (Kiss et al., 1995). Contudo, como estes autores afirmam que o método de estiolamento tem a vantagem de evitar danos na região de regeneração e impedir a formação de calo, é possí-

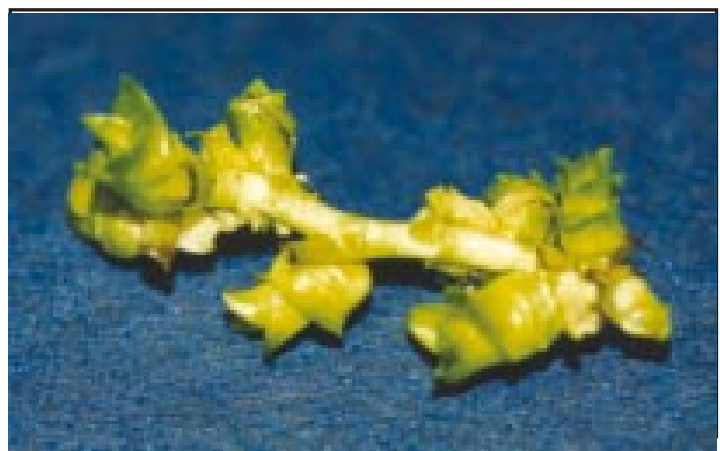

Figura 6. Plântulas de abacaxi híbrido $\mathrm{PE}$ x SC-52 regeneradas em meio MS com ANA a $1,86 \mathrm{mg} / \mathrm{L}$.

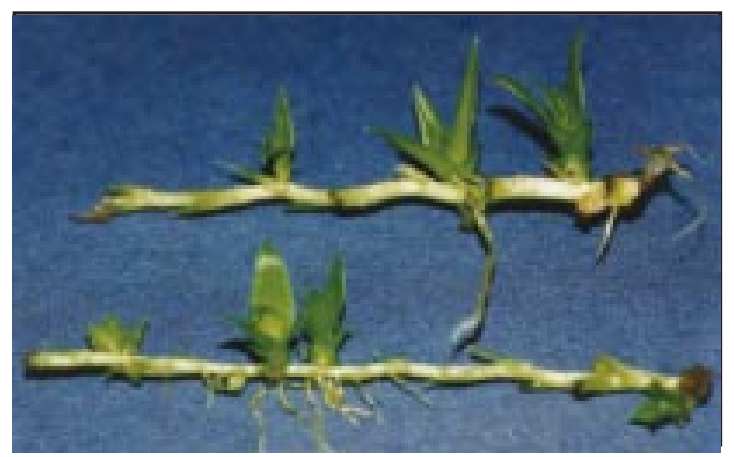

Figura 7. Plântulas de abacaxi híbrido PE x SC-52 regeneradas em meio MS sem reguladores de crescimento. vel que este método proporcione menores taxas de variabilidade que os protocolos mais convencionais de micropropagação (Rao et al., 1981; Ramirez, 1984; Dewald et al., 1988).

Este método é diferente de outros protocolos mais convencionais, e mostrou ser eficaz na regeneração de plântulas. Tendo em vista a ocorrência de variantes entre plântulas de abacaxi micropropagadas, seria interessante a avaliação e comparação do material produzido neste método com o material produzido em outros protocolos. No entanto, até o presente, segmentos nodais não foram utilizados para produção de mudas de abacaxi em larga escala.

\section{Conclusões}

1. O método do estiolamento de segmentos nodais e regeneração de plântulas é viável para a multiplicação in vitro do abacaxi híbrido PE x SC-52.

2. ANA a $1,86 \mathrm{mg} / \mathrm{L}$ para estiolamento de brotos, seguido de BAP a $2 \mathrm{mg} / \mathrm{L}$ para regeneração de plântulas, são os melhores tratamentos para a multiplicação in vitro do híbrido PE x SC-52, usando segmentos nodais estiolados.

\section{Referências}

DEWALD, M. G.; MOORE, G. A.; SHERMAN, W. B.; EVANS, M. H. Production of pineapple plants in vitro. Plant Cell Reports, Berlin, v. 7, n. 7, p. 535-537, 1988.

DUDITS, D.; BORGRE, L.; GYORGYEY, L. Embryo development from somatic plants cells in vitro: molecular and cellular basis. Journal of Cell Science, Cambridge, Grã-Bretanha, v. 99, p. 473-482, 1991.

GRATTAPAGLIA, D.; MACHADO, M. A Micropropagação. In: TORRES, A. C.; CALDAS, L. S.; BUSO, J. A. (Ed.). Cultura de tecidos e transformação genética de plantas. Brasília : Embrapa-SPI/EmbrapaCNPH, 1998. v. 1, p. 183-260

HESZKY, L. E.; NAGY, M. In vitro conservation of potato germplasm in Hungary. In: BAJAJ, Y. P. S. (Ed.). Biotechnology in agriculture and forestry. 3. Potato. Berlin : Springer, 1987. p. 465-490.

KISS, J.; HESZKY, L. E.; KISS, E.; GYULAI, G. High efficiency adventive embryogenesis on somatic embryos of anther, filament and immature proembryo origin in horse-chestnut (Aesculus hippocastanum) tissue culture. Plant Cell, Tissue and Organ Culture, Dordrecht, v. 30, p. 59-64, 1992. 
KISS, E.; KISS, J.; GYULAI, G.; HESZKY, L. E. A novel method for rapid micropropagation of pineapple. HortScience, Alexandria, v. 30, n. 1, p. 127-129, 1995.

MALIGA, P.; BREZNOVITS,A. S.; MÁRTON, L.; JOÓ, F. Non-Mendelian streptomycin-resistant tobacco mutant with altered chloroplasts and mitochondria. Nature, London, n. 225, p. 401-405, 1975.

MARINUS, J. Methods for rapid multiplication of potatoes. Potato Research, Wageningen, v. 27, p. 317 , 1984.

MURASHIGE, T.; SKOOG, F. A revised medium for rapid growth and bioassays with tobacco tissue cultures. Physiologia Plantarum, Copenhagen, v. 15, p. 473-497, 1962

PASQUAL, M.; MOREIRA, M. A.; ANJOS SOBRINHO, A. dos. Biotecnologia aplicada à produção de mudas de abacaxi. Informe Agropecuário, Belo Horizonte, v. 19, n. 195, p. $20-23,1998$.

RAMIREZ, A. L. Reproduction of pineapple (Ananas comosus L. Merr.) by tissue culture. Cultivos Tropicales, Havana, v. 63, p. 681-697, 1984
RAO, N. K. S.; SWAMY, R. D.; CHACO, E. K. Differentiation of plantlets in hybrid embryo callus of pineapple. Scientia Horticulturae, Amsterdam, v. 15, p. $235-238,1981$.

REINHARDT, D. H. R. C. Manejo e produção de mudas de abacaxi. Informe Agropecuário, Belo Horizonte, v. 19, n. 195 , p. $13-19,1998$

ROCA, W. M.; ESPINOZA, N. O.; ROCA, M. N.; BRYAN, J. E. A tissue culture method for the rapid propagation of potatoes. American Potato Journal, Orono, v. 55, p. 691-706, 1978

VÁLIO, I. F. M. Auxinas. In: FERRI, M. G. (Ed.). Fisiologia vegetal. São Paulo : EPU, 1986. v. 2, p. 39-72.

VENTURA, J. A.; ZAMBOLIM, L.; CHAVES, G. M. Integrated management system for pineapple Fusarium disease control. Acta Horticulturae, Leuven, n. 334, p. 439-454, 1993.

WASAKA, K. Variation in the plants differentiated from the tissue culture pineapple. Japanese Journal of Breeding, Tokyo, v. 29, n. 1, p. 13-22, 1979. 